\title{
Studi Pelacakan (Tracer Study) Kinerja Lulusan Program Pascasarjana Magister Ilmu Ekonomi (MIE) Fakultas Ekonomi Dan Bisnis Universitas Mataram
}

\author{
Budi Santoso $^{1^{*}}$, Hadi Mahmudi ${ }^{1}$ dan Prayitno Basuki ${ }^{1}$
}

1 Prodi Magister Ilmu Ekonomi, Fakultas Ekonomi dan Bisnis, Universitas Mataram *email korespondensi : hebato@yahoo.com

Info Artikel

ABSTRAK

Kata Kunci:

Proses pembelajaran

Soft dan hard skills

Kinerja alumni

\begin{abstract}
Penelitian ini bertujuan untuk mengkaji: a) Kondisi Proses belajar mengajar dan manajemen internal di Prodi MIE UNRAM. b) Kebutuhan soft dan hard skills lulusan/ alumni Prodi MIE UNRAM. c) Penilaian pengguna terhadap kinerja lulusan Prodi MIE UNRAM. Data dikumpulkan melalui wawancara terhadap sebelas orang responden alumni Prodi MIE UNRAM yang tersebar di Provinsi Nusa Tenggara Barat. Hasil penelitian menunjukan bahwa Alumni menyatakan pentingnya pengalaman magang, penekanan besar terhadap aspek peragaan atau demontrasi materi perkuliahan, dan pembimbingan akademik bernilai besar dalam proses pembelajaran. Sedangkan soft dan hard skills yang mereka butuhkan adalah kemampuan mengkomunikasikan hasil penelitian, dan gagasan mereka dengan dunia praktik. Didapati pula bahwa responden alumni sangat mampu bersaing dengan alumni perguruan tinggi lain baik dalam memperoleh pekerjaan maupun dalam penyelesaian pekerjaan di organisasi mereka.
\end{abstract}

\section{Latar Belakang}

Dari waktu ke waktu dunia pendidikan senantiasa dihadapkan pada sejumlah permasalahan yang nyaris tak terpecahkan. Hal ini disebabkan oleh dinamika kehidupan manusia dan masyarakat itu sendiri berkembang sangat cepat, demikian juga perkembangan ilmu dan teknologi, sehingga tuntutan akan kompetensi individu senantiasa berubah dan mengalami perkembangan dari waktu ke waktu. Kompetensi individu merupakan produk dari proses pendidikan yang dialaminya. Secara garis besar permasalahan pendidikan di Indonesia sampai dengan awal tahun 2000an dapat dikelompokkan menjadi tiga: 1) 
pemerataan pendidikan dan perluasan akses, 2) peningkatan mutu, relevansi, dan daya saing, dan 3) penguatan tata kelola, akuntabilitas, dan pencitraan publik.

Sejauh ini berbagai upaya telah dilakukan untuk mengatasi permasalahan tersebut, baik melalui kebijakan yang bersifat makro maupun mikro. Berbagai upaya tersebut ternyata belum membuahkan hasil sebagaimana diharapkan. Khusus terkait dengan persoalan relevansi, hingga awal tahun 2000 masih belum terwujud situasi yang menunjukkan adanya keterkaitan yang erat antara dunia pendidikan dengan dunia kerja, padahal antara keduanya seharusnya terjalin kerjasama yang sinergis. Dunia pendidikan seakan-akan berjalan sendiri, tanpa merisaukan kebutuhan dunia kerja. Demikian juga dunia kerja seolah berjalan sendiri tanpa harus besinggungan dengan dunia pendidikan. Rendahnya relevansi tersebut tidak hanya terjadi pada tingkat sekolah menengah tetapi juga perguruan tinggi (PT). Untuk level perguruan tinggi, dapat dilihat misalnya dari banyaknya lulusan PT (sarjana) yang menganggur. Dari tahun ke tahun angka pengangguran terdidik semakin bertambah. Fakta ini tentu sangat memprihatinkan dan sekaligus disayangkan, karena sebenarnya bangsa Indonesia masih sangat memerlukan tenaga terdidik dalam jumlah besar untuk melanjutkan pembangunan dan meningkatkan kemampuan bangsa dalam memasuki persaingan global.

Persoalan pengangguran tersebut antara lain disebabkan oleh kurang sesuainya kompetensi yang dimiliki lulusan dengan tuntutan dunia kerja. Dengan kata lain, keterkaitan antara program pendidikan yang diselenggarakan oleh lembaga pendidikan dengan kebutuhan dunia kerja, masih rendah. Kondisi seperti itu menimbulkan dampak negatif berganda. Di satu sisi masyarakat dan pemerintah harus mengeluarkan biaya pendidikan yang sangat besar, di sisi yang lain kompetensi yang dimiliki lulusan ternyata tidak sesuai dengan kebutuhan lapangan. Dengan kata lain terjadi ketidakefektifan dalam penyelenggaraan pendidikan.

Untuk mengetahui tingkat relevansi antara program pendidikan yang diselenggarakan oleh sebuah lembaga pendidikan (termasuk perguruan tinggi) dengan kebutuhan lapangan, maka diperlukan kajian terhadap lulusan yang dihasilkan. Dari studi penelusuran seperti itu diperoleh berbagai informasi penting, antara lain kebutuhan riil yang diperlukan dunia kerja, kekurangan yang dimiliki lulusan, kelemahan kurikulum yang selama ini digunakan, dan harapan alumni terhadap almamaternya terkait dengan penyelenggaraan pendidikan ke depan.

Sejak program pascasarjana UNRAM menyelenggarakan program studi Master Ilmu Ekonomi (MIE) tahun 2012 hingga saat ini (tahun 2018) baru dua kali dilakukan studi penelusuran lulusan. Oleh karena itu perlu dilakukan penelitian untuk mengetahui kinerja lulusan di "lapangan" pada saat dan mendapatkan berbagai informasi penting yang diperlukan dalam rangka mengembangkan program studi ke depan.

\section{Tujuan}

Adapun tujuan penilitian ini adalah untuk mengkaji:

a. Kondisi Proses belajar mengajar dan manajemen internal di Prodi MIE UNRAM;

b. Kebutuhan soft dan hard skills lulusan/ alumni Prodi MIE UNRAM; dan

c. Kinerja lulusan Prodi MIE UNRAM. 


\section{Kajian Kepustakaan}

\subsection{Studi Penelusuran (Tracer Study)}

Penelusuran lulusan (tracer study) merupakan bagian penting dari aktivitas sebuah lembaga pendidikan. Melalui penelusuran lulusan akan diperoleh berbagai informasi penting yang sangat bermanfaat bagi lembaga pendidikan yang bersangkutan, bagi para lulusan, dan juga lembaga-lembaga lain yang terkait dengan penyelenggaraan pendidikan. Tracer study memungkinkan sebuah lembaga pendidikan melacak kondisi lulusan yang dihasilkan dan dari informasi yang diperoleh dapat diambil berbagai kebijakan dan tindakan yang memberikan manfaat bagi para lulusan dan bagi pengembangan lembaga yang bersangkutan. Salah satu manfaat penting dari penelitian tracer study adalah diperolehnya informasi tentang relevansi program pendidikan yang diselenggarakan dengan kebutuhan lapangan. Menjamin adanya relevansi antara program pendidikan dengan kebutuhan lapangan merupakan keharusan bagi setiap lembaga pendidikan. Undang-undang Republik Indonesia Nomor 20 Tahun 2003 tentang Sistem Pendidikan Nasional menjelaskan bahwa sistem pendidikan nasional harus mampu menjamin pemerataan kesempatan pendidikan, peningkatan mutu, serta relevansi, dan efisiensi manajemen pendidikan untuk menghadapi tantangan sesuai dengan tuntutan perubahan kehidupan lokal, nasional, dan global.

Finch, dkk (Patni Ninghardjanti, 1999: 43) mengemukakan bahwa studi penelurusan bertujuan untuk mengetahui mobilitas tamatan dan kepuasan tamatan terhadap pekerjaannya. Mobilitas tamatan dapat dilihat dari mobilitas karir, baik secara vertikal maupun horizontal. Mobilitas karir secara vertikal dapat ditelusuri melalui jenjang jabatan pekerjaan yang diperoleh tamatan sedangkan mobilitas horizontal ditelusuri melalui banyaknya tamatan yang melakukan perpindahan tempat kerja. Berdasarkan hasil penelusuran lulusan, sekolah dapat melakukan berbagai tindakan yang diharapkan mampu meningkatkan kualitas sekolah yang bersangkutan. Pemanfaatan hasil studi penelusuran juga memungkinkan sekolah melakukan perubahan dan penyesuaian sehingga sustainabilitas sekolah lebih menjamin.

Slamet PH (1993) mengemukakan bahwa studi penelusuran bertujuan untuk mengetahui: sejarah karir tamatan, status karir/pekerjaan tamatan, dan penilaian tamatan terhadap program pendidikan atas dasar pengalaman kerja mereka. Meyer, dkk. (Patni Ninghardjanti, 1999: 44) mengklasifikasi tujuan studi penelusuran menjadi tiga hal: 1) untuk memperbaiki pengajaran dan pembelajaran di sekolah, 2) untuk membantu alumni dalam mencari pekerjaan, dan 3) untuk mengumpulkan informasi penting sehingga dapat digunakan untuk memperbaiki program.

Kinerja

Studi penelusuran juga dimaksudkan untuk mengetahui penampilan (antara lain berupa kinerja dan produktivitas) lulusan setelah mereka terjun ke masyarakat. Banyak faktor yang mempengaruhi penampilan seseorang. Bernadin \& Russel (Suwardjo, 2003: 26) mengemukakan bahwa produktivitas seseorang dipengaruhi oleh faktor penguasaan pengetahuan, keterampilan, sikap, dan tingkahlaku pekerja dalam organisasi. Penguasaan pengetahuan dan keterampilan yang memadai serta dimilikinya sikap dan tingkahlaku yang positif, menyebabkan seseorang memiliki tingkat produktivitas yang tinggi. Demikian juga sebaliknya. Faktor-faktor 
tersebut sebagian besar terbentuk ketika seseorang mengikuti pendidikan dan pelatihan sebelumnya. Itu berarti bahwa proses pembelajaran yang baik di sekolah, mampu membekali lulusan sehingga yang bersangkutan memiliki produktivitas yang tinggi.

Sementara itu, menurut Sutalaksana (Suwardjo, 2003: 26) kinerja seseorang dapat dibedakan menjadi dua: faktor diri dan faktor situasional. Faktor diri mencakup sejumlah aspek antara lain: bakat, minat, usia, jenis kelamin, pendidikan, pengalaman, dan motivasi; sedangkan faktor situasional adalah faktor yang berasal dari luar orang yang bersangkutan misalnya faktor fisik pekerjaan. Dari paparan di atas nampak bahwa faktor pendidikan yang diperoleh seseorang ikut menentukan penampilan seseorang setelah yang bersangkutan terjun ke masyarakat.

$\begin{array}{rcr}\begin{array}{r}\text { Khusus } \\ \text { perkembangan }\end{array} & \text { terkait } & \begin{array}{r}\text { dengan } \\ \text { karir }\end{array}\end{array}$
pendidikan yang diperoleh sebelumnya juga sangat menentukan. Yang dimaksud dengan karir menurut Flippo (1985: 248) adalah ".. a sequence of separate but related work activities that provide continuity, order, and meaning in a person life" (pekerjaan yang terdiri dari sejumlah aktivitas terpisah namun berurutan dan saling terkait, yang memberikan kelangsungan, keteraturan, dan bermakna dalam kehidupan seseorang). Sedangkan menurut Cascio \& Awad (1981: 273) istilah karir mencakup tiga pengertian sebagai berikut:

1. Career as a sequence of promotions for lateral transfer to more responsible jobs or to better location within or across a work-related hierarchy during a person's work years; (Karir sebagai urutan promosi yang terkait dengan perubahan pekerjaan yang lebih bertanggung jawab atau pekerjaan yang lebih baik di dalam atau di hirarki yang berhubungan dengan pekerjaan seseorang selama bertahun-tahun)

2. Carees as referring to those occupations to provide a clear pattern of systematic advancement a carrer ladder, or path; (Karir sebagai rujukan pada suatu pekerjaan untuk memberikan pola yang jelas kemajuan tangga kariir secara sistematis, atau jalur)

3. Carrer as a person's job history, a series of positions held over an entire work life. (Karis sebagai sejarah pekerjaan seseorang, serangkaian jabatan lebih dari satu dalam seluruh kehidupan kerja).

Pendidikan seseorang, dalam arti pengalaman yang diperoleh selama mengikuti proses pembelajaran, ikut menentukan perkembangan karir di masa mendatang. Dengan kata lain, terdapat relevansi yang tinggi antara pendidikan dengan karir seseorang.

\subsection{Pengembangan Organisasi}

Pada bagian dibahas secara mendetail tentang konsep, tujuan dan asumsi dasar dalam pengembangan organisasi. Bahasan ini secara umum tentang pengembangan organisasi secara luas.

\section{Konsep Pengembangan}

Dalam penggunaan sehari-hari, istilah pengembangan sering digabungkan dengan penelitian sehingga menjadi penelitian dan pengembangan organisasi. Hal ini dapat dimengerti karena pengembangan organisasi memang erat kaitannya dengan aktivitas penelitian sehingga masuk akal apabila kedua kegiatan tersebut digabungkan. Pada sejumlah organisasi, aktivitas tersebut ditangani oleh bagian khusus yang sengaja dibentuk untuk itu. Istilah yang digunakan untuk menamakan bagian tersebut bermacam-macam. Di Indonesia, sebutan yang banyak digunakan ialah bagian 
penelitian dan pengembangan organisasi (balitbang).

Dari studi tentang organisasi dijumpai berbagai batasan tentang istilah pengembangan organisasi. Pada umumnya orang mengartikan pengembangan organisasi sebagai konsep yang menunjuk kepada proses penyiapan dan pengelolaan perubahan melalui penerapan ilmu tingkahlaku (behavior science). Sementara itu Rush (Gibson, J.L. et.al., 1988: 693-694) mendefinisikan pengembangan organisasi sebagai salah satu proses perubahan kebudayaan, sistem, dan tingkahlaku organisasi yang dilakukan secara terencana, terarah, dan sistematik, guna meningkatkan keefektifan organisasi dalam memecahkan problemproblem yang timbul dan dalam mencapai tujuan yang telah ditentukan (Organization develompent is planned, managed, systematic process to change the culture, systems, and behaviour of an organization, in order to improve the organization's effectiveness in solving its problems and achieving its objectives). Jadi sekurang-kurangnya terdapat tiga hal yang mencirikan pengembangan organisasi, yaitu :

a. Bahwa pengembangan organisasi merupakan suatu proses perubahan.

b. Perubahan tersebut dilakukan secara sengaja, artinya memang dikehendaki dan direncanakan.

c. Proses tersebut bertujuan meningkatkan keefektifan organisasi.

Secara lebih terinci, Beer (Minner, 1985: 321) mengemukakan bahwa pengembangan organisasi merupakan suatu proses pengumpulan data, diagnosis, perencanaan tindakan, intervensi dan perubahan, serta evaluasi hasil, yang diterapkan pada keseluruhan organisasi atau sebagian dari komponenkomponennya. Proses itu dimaksudkan untuk : a. Meningkatkan integrasi dan keserasian antar struktur, proses strategi, orang, dan budaya dalam organisasi

b. Mengembangkan kretivitas pemecahan masalah organisasi.

c. Mengembangkan kemampuan organisasi dalam memperbaharui diri sehingga sanggup menyesuaikan dengan perubahan yang terjadi diluar organisasi (faktor eksternal).

\subsection{Tujuan Pengembangan Organisasi}

Secara tidak langsung pada uraian di depan telah disinggung tujuan program pengembangan organisasi. Tujuan tersebut secara garis besar dapat dibedakan menjadi dua yaitu (1) meningkatkan keefektifan organisasi, dan (2) meningkatkan kepuasan kerja bagi para anggota. French (Matteson, 1989: 510) mengemukakan tujuan pengembangan organisasi secara lebih rinci, yang meliputi :

a. Mempertinggi tingkat kepercayaan dan dukungan diantara para anggota organisasi.

b. Menumbuhkan konflik sehingga mencapai tingkat optimal dalam memecahkan masalah organisasi, baik dalam maupun antar kelompok.

c. Menciptakan kondisi yang memungkinkan anggota memperoleh pengetahuan dan keterampilan tertentu sehingga memperkuat kewenangan resmi yang diperolehnya lewat jalur formal.

d. Mempertinggi tingkat keterbukaan komunikasi, baik yang bersifat horizontal, vertikal maupun diagonal. 
e. Mempertinggi tingkat antuisiasme pribadi dan kepuasan anggota dalam organisasi.

f. Menemukan pemecahan problem secara terpadu.

g. Mempertinggi rasa tanggung jawab anggota baik dalam kedudukannya sebagai pribadi maupun kelompok, dalam rangka perencanaan dan pelaksanaan tugas-tugas organisasi.

Jika diperhatikan, apa yang dikemukakan French di atas ternyata banyak berhubungan dengan faktor manusia dalam kedudukannya sebagai anggota organisasi. Dengan demikian dapat dikemukakan bahwa pengembangan organisasi merupakan upaya peningkatan keefektifan organisasi dengan penekanan pada faktor manusianya.

\subsection{Asumsi Dasar dalam Pengembangan Organisasi}

Program pengembangan organisasi akan berhasil mencapai sasaran yang diharapkan jika kondisi yang dihadapi sesuai dengan asumsi-asumsi berikut :

\section{a. Asumsi tentang individu}

1. Pada umumnya individu memiliki dorongan untuk tumbuh dan berkembang; dan dorongan tersebut dapat dipenuhinya lewat lingkungan yang mendukung serta menantang.

2. Pada umumnya individu ingin dan mampu memberikan sumbangan dalam rangka mencapai tujuan organisasi, jauh lebih besar dari yang dimungkinkan oleh lingkungan organisasi.

b. Asumsi tentang individu dalam kelompok.

1. Pada umumnya individu ingin diterima sebagai anggota kelompok dan berorientasi pada sekurangkurangnya satu kelompok, misalnya kelompok kerja dan keluarga.

2. Salah satu kelompok yang secara psikologis relevan bagi sebagian besar orang ialah kelompok kerja (kelompok tempat mereka bekerja), termasuk di dalamnya teman-teman sejawat dan atasan.

3. Pada umumnya orang memiliki kemampuan yang cukup besar untuk meningkatkan keefektifan dalam membantu kelompoknya memecahkan problem yang dihadapi dan bekerjasama secara efektif di dalamnya.

4. Untuk mengoptimalkan keefektifan suatu kelompok, pimpinan tidak dapat melaksanakan fungsi-fungsi kepemimpinannya pada semua situasi dan waktu; dan seluruh anggota kelompok harus saling membantu satu sama lain dengan menunjukkan tingkahlaku dan kepemimpinan yang efektif.

c. Asumsi tentang individu dalam organisasi sebagai suatu system.

1. Organisasi cenderung dicirikan oleh adanya kerancuan saling ketergantungan kelompok kerja, dan kurang jelasnya fungsi penghubung yang dimiliki oleh pengawas maupun pimpinan yang lain.

2. Apa yang terjadi dalam organisasi sebagai keseluruhan mempengaruhi kelompok-kelompok kecil yang ada di dalamnya. Demikian juga sebaliknya, apa yang terjadi pada kelompok-kelompok kecil mempengaruhi organisasi secara leseluruhan.

3. Apa yang terjadi pada salah satu bagian organisasi (yaitu aspekaspek: sosial, teknologi, maupun administratif) mempengaruhi dan juga dipengaruhi oleh bagian lain. 
4. Budaya yang ada pada kebanyakan organisasi cenderung menekan perasaan anggota dalam memandang sesama rekannya, organisasi, dan diri mereka sendiri.

5. Perasaan yang tertekan tersebut mempengaruhi cara pemecahan masalah, pertumbuhan pribadi, dan kepuasan kerja anggota.

6. Tingkat kepercayaan, dukungan, dan kerjasama antar pribadi pada kebanyakan organisasi jauh lebih rendah dari yang diperlukan organisasi.

7. Strategi „menang-kalah"e (win-lose) dalam memecahkan problem organisasi bukan merupakan strategi optimal yang menguntungkan untuk jangka panjang, meskipun pada situasisituasi tertentu cocok diterapkan.

8. Pemecahan problem secara terpadu dapat dilakukan dengan frekuensi yang jauh lebih tinggi dari pada yang senyatanya dilakukan oleh kebanyakan organisasi.

9. Pandangan bahwa faktor perasaan merupakan sesuatu yang penting bagi organisasi cenderung membuka jalan bagi pengembangan tujuan, kepemimpinan, komunikasi, pemecahan masalah, kerjasama dalam kelompok, dan moral.

10. Peningkatan penampilan (output) melalui pengembangan organisasi memerlukan dukungan berupa perubahan yang tepat dalam hal: penghargaan, kompensasi, latihan, penempatan, dan spesialisasi tugas anggota. Pendeknya, dalam keseluruhan sistem kepegawaian. Proses berlangsungnya pengembangan organisasi berjalan di atas berbagai asumsi yang disebutkan di atas. Kadar keberhasilan pengembangan organisasi ditentukan oleh tingkat kesesuaian situasi yang senyatanya dihadapi dengan situasi yang tergambar dalam berbagai asumsi tersebut. Semakin jauh perbedaan antara ke dua situasi tersebut, semakin kecil kemungkinan berhasilnya pencapaian tujuan pengembangan organisasi. Sebagai contoh, salah satu asumsi dasar tentang individu mengatakan bahwa orang memiliki keinginan dan kemampuan untuk memberikan sumbangan dalam rangka pencapaian tujuan organisasi. Jika dalam kenyataannya anggota organisasi tidak memiliki keinginan untuk membantu organisasi dalam mencapai tujuannya (meskipun dia sendiri sebenarnya mampu) maka tujuan pengembangan organisasi, yaitu meningkatkan keefektifan organisasi, tidak akan tercapai. Atau bisa jadi anggota berkeinginan menyumbang pencapaian tujuan organisasi, tetapi karena ia tidak memiliki kemampuan untuk itu, maka kondisi ini pun tidak mendukung pencapaian tujuan pengembangan organisasi.

\section{Metode Penelitian}

Penelitian dilakukan dengan melakukan wawancara berdasarkan kuesionair. Responden penelitian ini adalah sebelas orang alumni yang bertempat tinggal di wilayah Provisnsi Nusa Tenggara Barat. Periode pengumpulan data dari bulan Juli sampai dengan Oktober 2018.

\section{Hasil Penelitian}

Pada bagian ini, kajian hasil penelitian dikelompokan berdasarkan tujuan penelitian ini, yaitu: pengalaman proses pembelejaran, soft dan hard skills diperlukan, dan kinerja alumni.

\subsection{Pengalaman Proses Pembelajaran}

Ada beberapa item yang ditanyakan dalam penelitian tentang 
pengalaman proses pembelajaran selama responden alumni mengikuti kuliah di
Prodi MIE Unram, sebagaimana tampak dalam tebel berikut ini.

Tabel Error! No text of specified style in document.-1 Pengalaman Dalam Proses Pembelajaran Responden Alumni Selama Kuliah di MIE Unram

\begin{tabular}{|l|r|r|r|r|r|}
\hline \multicolumn{1}{|c|}{ Pengalaman } & $\begin{array}{c}\text { Tidak } \\
\text { Penting }\end{array}$ & $\begin{array}{r}\text { Kurang } \\
\text { Penting }\end{array}$ & Penting & $\begin{array}{c}\text { Sangat } \\
\text { Penting }\end{array}$ & $\begin{array}{c}\text { Tidak } \\
\text { Ada }\end{array}$ \\
\hline Belajar di dalam kelas & $0,00 \%$ & $0,00 \%$ & $36,36 \%$ & $63,64 \%$ & $0,00 \%$ \\
Belajar di laboratorium & $0,00 \%$ & $9,09 \%$ & $54,55 \%$ & $36,36 \%$ & $0,00 \%$ \\
Belajar di masyarakat/komunitas & $0,00 \%$ & $0,00 \%$ & $27,27 \%$ & $72,73 \%$ & $0,00 \%$ \\
Magang perusahaan/instansi & $0,00 \%$ & $0,00 \%$ & $36,36 \%$ & $63,64 \%$ & $0,00 \%$ \\
Belajar dalam pergaulan kampus & $0,00 \%$ & $0,00 \%$ & $45,45 \%$ & $54,55 \%$ & $0,00 \%$ \\
Belajar mandiri & $0,00 \%$ & $0,00 \%$ & $36,36 \%$ & $63,64 \%$ & $0,00 \%$ \\
\hline
\end{tabular}

Sumber: Data Primer Diolah, 2018

Indikator pengalaman proses pembelajaran responden didominasi oleh pernyataan sangat penting sebagaimana terlihat dalam Tabel Error! No text of specified style in document.-1 dan Grafik Error! No text of specified style in document.-1. Hanya satu item pernyataan yang responden nyatakan sangat penting dibawah pernyataan penting, yaitu berkaitan dengan item pernyataan pengalaman belajar di laboratorium dengan pernyataan penting sebanyak 54,55 persen, sedangkan yang menyatakan sangat penting sebanyak 36,36 persen. Lebih lanjut, menyatakan kurang penting sebanyak 9,09 persen. Ini berarti bahwa dapat dikatakan pengalaman belajar di laboratorium kurang penting dalam proses pembelaran di Prodi MIE Unram.

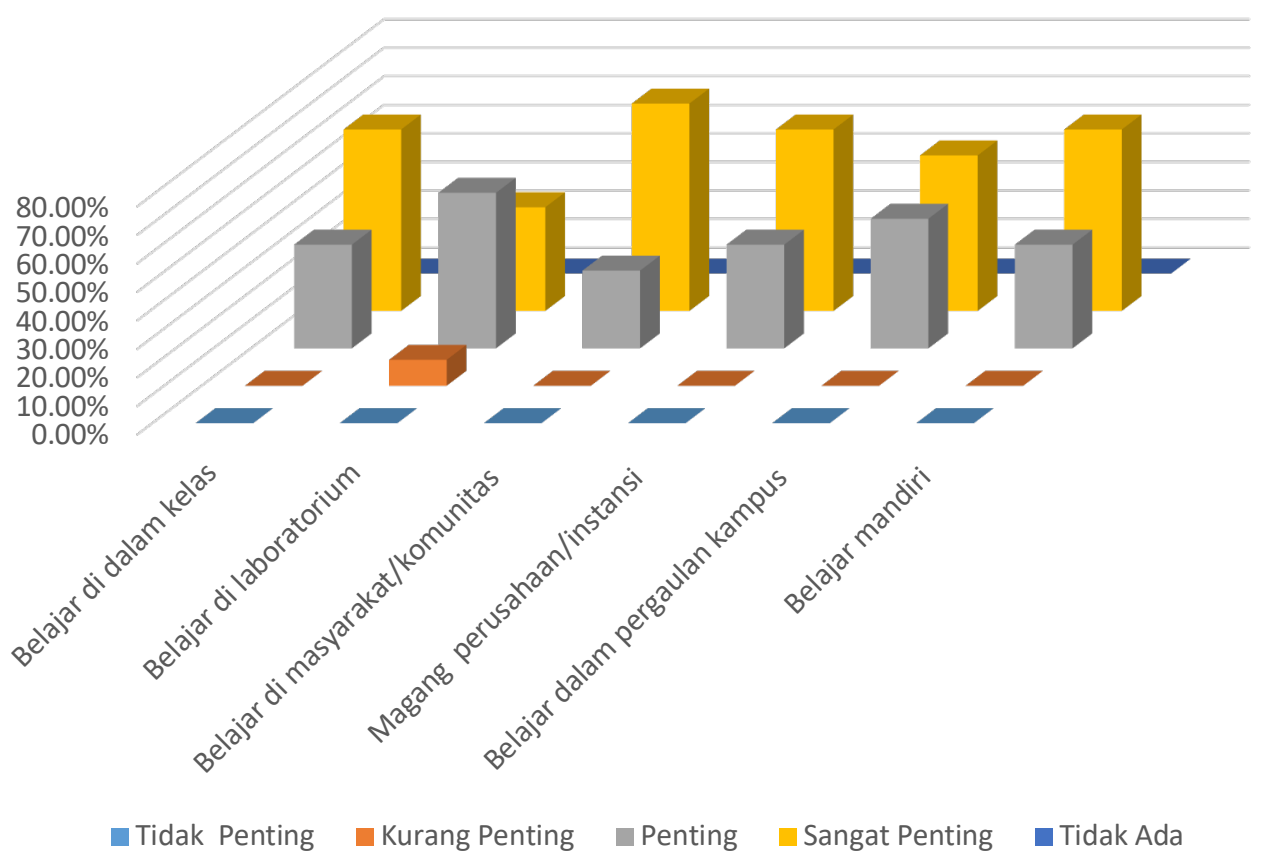


Grafik Error! No text of specified style in document.-1 Pengalaman Proses Pembelajaran Responden Selama Kuliah di MIE Unram

Dalam Tabel Error! No text of specified style in document.-1 dan Grafik Error! No text of specified style in document.-1 tercermin pula responden alumni menyatakan pengalaman-pengalaman belajar di dalam kelas, masyarakat/ komunitas, magang, belajar dalam pergaulan kampus, dan belajar mandiri merupakan hal yang sangat penting bagi mereka.

\subsection{Penekanan Aspek Pembelajaran}

Sebagaimana terlihat dalam Tabel Error! No text of specified style in document.2 dan Grafik Error! No text of specified style in document.-2 bahwa pernyataan responden terhadap penekanan aspek pembelajaran di Prodi MIE Unram sangat beragam. Sebanyak 45,45 persen responden menyatakan perlunya penekanan besar terhadap aspek perkuliahan, yang menyatakan perlu penekanan sangat besar sebanyak 36,36 persen. Ada juga yang menyatakan kurang perlunya penekanan dari aspek perkuliahan, dan ada pula yang menyatakan penekanan sudah cukup dari aspek perkuliahan. Dari Tabel Error! No text of specified style in document.-2 dan Grafik Error! No text of specified style in document.-2 juga terurai bahwa ada tiga item dalam indikator ini medapat perhatian ekstrim dari responden, yaitu: aspek peragaan, partisipasi dalam proyek riset, dan pemberian tugas. Sebanyak 72,73 persen responden menyatakan perlunya penekanan besar terhadap aspek demontrasi (peragaan), sebanyak 72,73 persen responden menyatakan kurang perlu berpartisipasi dalam proyek riset dengan alasan mereka sudah cukup sibuk dengan tugas perkuliahan dan pekerjaan kantor mereka.

Tabel Error! No text of specified style in document.-2 Pernyataan Responden Terhadap Penekanan Aspek Pembelajaran di Prodi MIE Unram

\begin{tabular}{|l|r|r|r|r|r|}
\hline Penekanan Aspek Pembelajaran & Kurang & \multicolumn{1}{l|}{ Cukup } & Besar & \multicolumn{1}{l|}{$\begin{array}{l}\text { Sangat } \\
\text { besar }\end{array}$} & Tidak Ada \\
\hline Perkuliahan & $9,09 \%$ & $9,09 \%$ & $45,45 \%$ & $36,36 \%$ & $0,00 \%$ \\
Demonstrasi (Peragaan) & $0,00 \%$ & $9,09 \%$ & $72,73 \%$ & $18,18 \%$ & $0,00 \%$ \\
Partisipasi dalam proyek riset & $72,73 \%$ & $0,00 \%$ & $0,00 \%$ & $27,27 \%$ & $0,00 \%$ \\
Praktikum/ kerja lapangan & $0,00 \%$ & $45,45 \%$ & $45,45 \%$ & $9,09 \%$ & $0,00 \%$ \\
Diskusi/ presentasi & $9,09 \%$ & $45,45 \%$ & $18,18 \%$ & $18,18 \%$ & $0,00 \%$ \\
Pemberian tugas & $0,00 \%$ & $27,27 \%$ & $63,64 \%$ & $9,09 \%$ & $0,00 \%$ \\
\hline
\end{tabular}

Sumber: Data Primer diolah, 2018. 


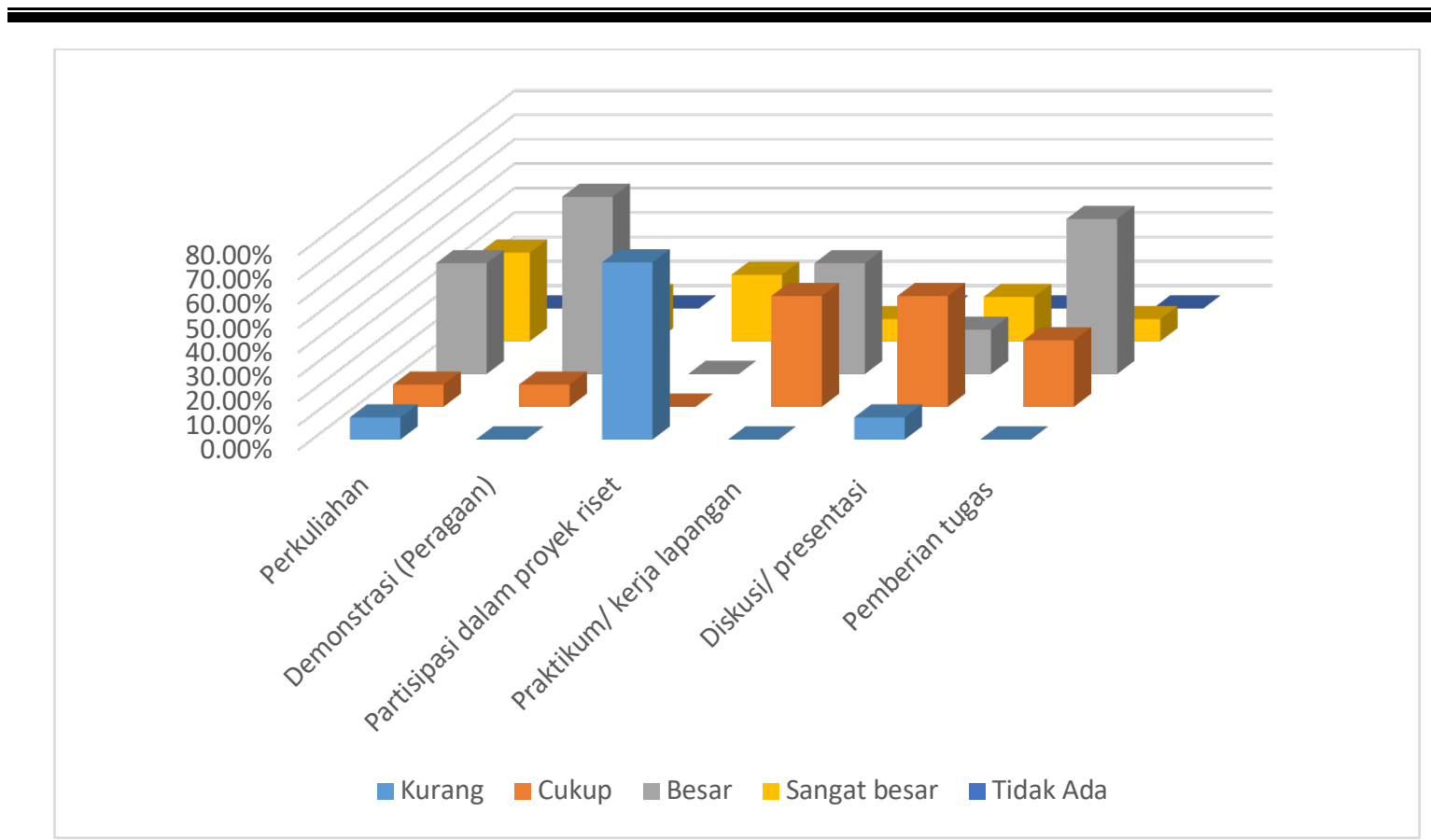

Grafik Error! No text of specified style in document.-2 Pernyataan Responden Terhadap Penekanan Aspek Pembelajaran di Prodi MIE Unram

Sebanyak 63,64 persen responden menyakan perlunya penekanan besar terhadap pemberian tugas individu atau kelompok agar mereka bisa bergaul dan berinteraksi sesama teman kuliah. Ada juga responden sebanyak 9,09 persen yang menyatakan kurang perlu penekanan pada aspek diskusi atau presentasi dengan alasan kesulitan mengatur waktu untuk mempersiapkan bahan presentasi.

\subsection{Penilaian Proses Pembelajaran}

Pola pernyataan dalam penilaian proses pembelajaran yang diberikan oleh respoden ada nya kesamaan dengan pola pernyataan dalam memberikan jawaban pada penekanan aspek pembelajaran. Hal ini tampak pada ilustrasi dalam tabel dan grafik berikut ini.

Tabel Error! No text of specified style in document.-3 Penilaian Responden Terhadap Proses Pembelajaran di Prodi MIE Unram

\begin{tabular}{|l|r|r|r|r|}
\hline \multicolumn{1}{|c|}{ Penilaian Terhadap } & Kurang & Cukup & Besar & \multicolumn{1}{|c|}{$\begin{array}{c}\text { Sangat } \\
\text { besar }\end{array}$} \\
\hline $\begin{array}{l}\text { Kesempatan untuk berinteraksi dengan dosen-dosen di } \\
\text { luar jadwal kuliah }\end{array}$ & $9,09 \%$ & $9,09 \%$ & $45,45 \%$ & $36,36 \%$ \\
\hline Pembimbingan akademik & $0,00 \%$ & $9,09 \%$ & $72,73 \%$ & $18,18 \%$ \\
\hline Kesempatan berpartisipasi dalam proyek riset & $72,73 \%$ & $0,00 \%$ & $0,00 \%$ & $27,27 \%$ \\
\hline Kondisi umum belajar mengajar & $0,00 \%$ & $45,45 \%$ & $45,45 \%$ & $9,09 \%$ \\
\hline $\begin{array}{l}\text { Kesempatan untuk memasuki dan menjadi bagian dari } \\
\text { jejaring ilmiah profesional }\end{array}$ & $9,09 \%$ & $36,36 \%$ & $27,27 \%$ & $18,18 \%$ \\
\hline
\end{tabular}

Sumber: Data Primer diolah, 2018 
Pada Tabel Error! No text of specified style in document.-3 dan Grafik Error! No text of specified style in document.-3 tercermin bahwa ada dua penilaian ekstrim, yaitu pada aspek pembimbingan akademik dan kesempatan berpartisipasi dalam proyek riset. Sebanyak 72,73 persen responden menilai besar peranan pembimbingan akademik dalam proses pembelajaran di Prodi MIE Unram, sedangkan sebaliknya sebanyak 72,73 persen responden menilai kurang terhadap keterlibatan mahasiswa dalam proyek riset. Dari sini nampak bahwa mahasiswa mendambakan bimbingan instensif dari pengajar karena sebagian besar dari mahasiswa sudah relatif lama meninggal bangku kuliah strata satu. Responden juga memerlukan kesempatan berinteraksi dengan dosendosen di luar jam kuliah, sebagaimana tercermin dari penilaian mereka, yaitu sebanyak 45,45 persen dan 36,36 persen menilai besar dan sangat besar terhadap aspek ini.

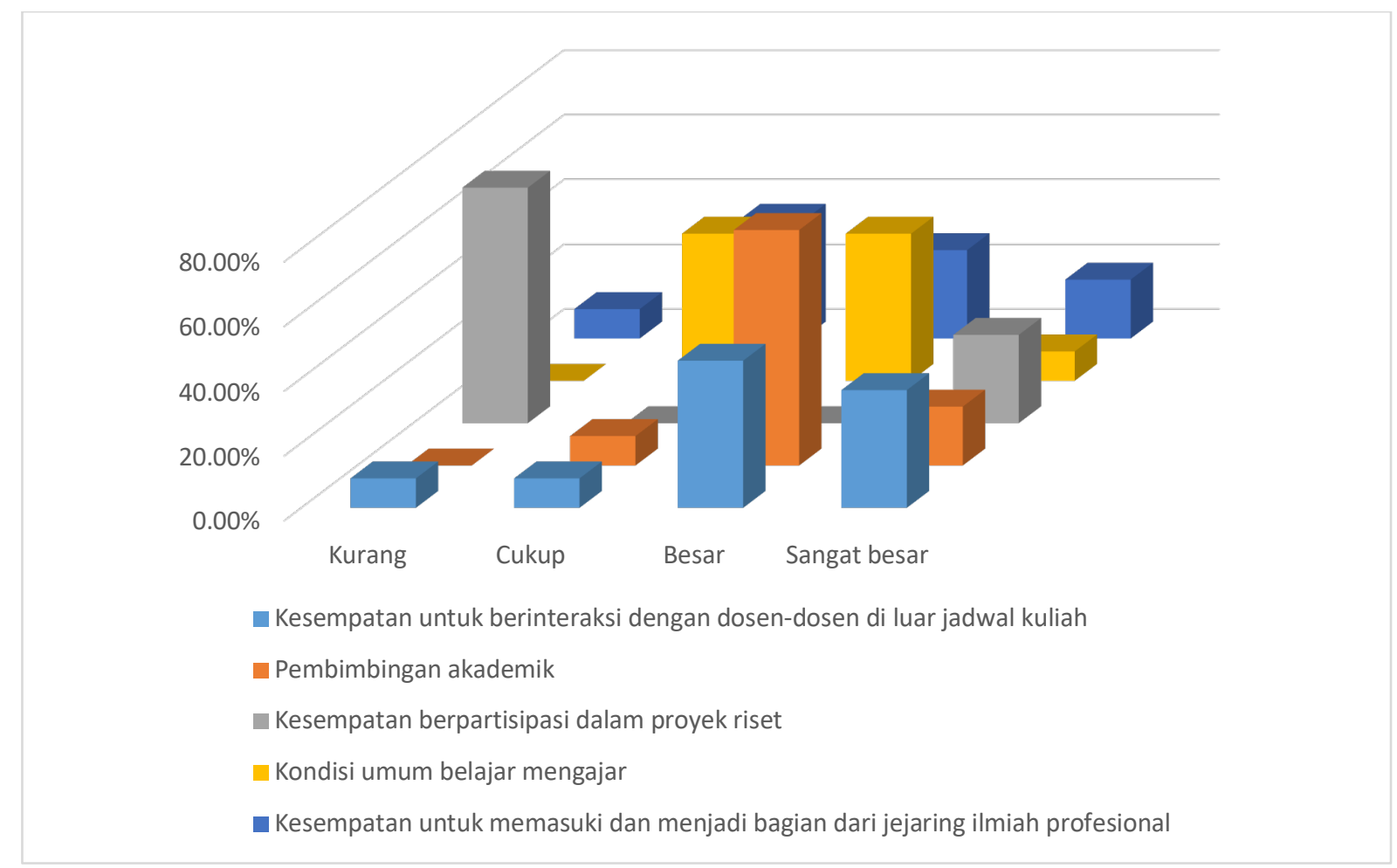

Grafik Error! No text of specified style in document.-3 Penilaian Responden Terhadap Proses Pembelajaran di Prodi MIE Unram

\subsection{Kebutuhan soft dan hard skills Lulusan/ Alumni}

Salah satu tantangan yang dihadapi oleh mahasiswa setelah lulus dari jenjang pendidikan strata dua adalah berhadapan langsung dan nyata dalam penyelesaian masalah di organisasi pada tingkat midle- level management ke atas di mana mereka bekerja. Secara tidak langsung tantangan tersebut juga merupakan tantangan bagi penyelengggara pendidikan strata dua dalam membekali calon alumni tentang soft dan hard skills yang mereka butuhkan di masa sekarang dan mendatang dalam 
dunia nyata di organisasi tempat mereka berprofesi. Untuk itu, penelitian ini telah mengumpulkan data pendapat responden alumni tentang kebutuhan soft dan hard skills yang mereka perlukan untuk dapat menyelesaikan masalah relevan dengan latar bidang kajian mereka selama menempuh pendidikan di Prodi MIE Unram. Hasil pengolahan data terkumpul dalam penelitian ini tentang soft dan hard skills dibutuhkan responden alumni dapat dilihat dalam tabel dan grafik berikut ini.

Tabel Error! No text of specified style in document.-4 Pendapat Responden Alumni Tentang Kebutuhan Kompetensi Soft dan Hard Skills Dalam Pekerjaan Mereka

\begin{tabular}{|c|c|c|c|c|}
\hline Kompetensi Soft dan Hard Skills & $\begin{array}{c}\text { Tidak } \\
\text { Penting }\end{array}$ & $\begin{array}{l}\text { Kurang } \\
\text { Penting }\end{array}$ & Penting & $\begin{array}{l}\text { Sangat } \\
\text { Penting }\end{array}$ \\
\hline Integritas (moral, etika dan profesionalisme) & $0,00 \%$ & $9,09 \%$ & $27,27 \%$ & $63,64 \%$ \\
\hline Penguasaan ilmu kekhasan prodi Saudara secara mendalam & $0,00 \%$ & $27,27 \%$ & $36,36 \%$ & $36,36 \%$ \\
\hline $\begin{array}{l}\text { Kemampuan merencanakan dan melakukan penelitian yang } \\
\text { inovatif di bidang prodi Saudra }\end{array}$ & $0,00 \%$ & $18,18 \%$ & $27,27 \%$ & $54,55 \%$ \\
\hline $\begin{array}{l}\text { Kemampuan melakukan intrepretasi dan analisis ilmu terkini } \\
\text { untuk mengatasi masalah melalui pendekatan inter atau } \\
\text { multi disiplin }\end{array}$ & $0,00 \%$ & $18,18 \%$ & $45,45 \%$ & 36,36 \\
\hline $\begin{array}{l}\text { Kemampuan memecahkan masalah kompleks yang } \\
\text { berkaitan dengan ilmu Saudara }\end{array}$ & $0,00 \%$ & $0,00 \%$ & $54,55 \%$ & $45,45 \%$ \\
\hline $\begin{array}{l}\text { Kemampuan mengkomunikasikan informasi spesifik dan } \\
\text { terkini berdasarkan hasil kajian (evidence based) }\end{array}$ & $0,00 \%$ & $18,18 \%$ & $54,55 \%$ & $27,27 \%$ \\
\hline $\begin{array}{l}\text { Kemampuan mempublikasikan hasil penelitian dalam jurnal } \\
\text { nasional/Internasional }\end{array}$ & $0,00 \%$ & $36,36 \%$ & $36,36 \%$ & $27,27 \%$ \\
\hline $\begin{array}{l}\text { Kemampuan mengkomunikasikan hasil penelitian dalam } \\
\text { forum ilmiah di tingkat nasional atau internasional }\end{array}$ & $0,00 \%$ & $9,09 \%$ & $81,82 \%$ & $9,09 \%$ \\
\hline $\begin{array}{l}\text { Kemampuan mengembangkan pengetahuan dan } \\
\text { mengintegrasikannya dengan ilmu pengetahuan mutakhir }\end{array}$ & $0,00 \%$ & $0,00 \%$ & $72,73 \%$ & $27,27 \%$ \\
\hline Kepemimpinan & $0,00 \%$ & $9,09 \%$ & $63,64 \%$ & $27,27 \%$ \\
\hline Kerjasama dalam tim & $0,00 \%$ & $9,09 \%$ & $45,45 \%$ & $45,45 \%$ \\
\hline Bahasa Inggris & $0,00 \%$ & $36,36 \%$ & $54,55 \%$ & $9,09 \%$ \\
\hline Komunikasi efektif & $0,00 \%$ & $18,18 \%$ & $63,64 \%$ & $18,18 \%$ \\
\hline Penggunaan teknolog informasi & $0,00 \%$ & $0,00 \%$ & $54,55 \%$ & $45,45 \%$ \\
\hline Pengembangan diri & $0,00 \%$ & $9,09 \%$ & $63,64 \%$ & $27,27 \%$ \\
\hline
\end{tabular}

Sumber: Data Primer diolah, 2018. 
Vol. 1 No. 1 (2019), 1-15

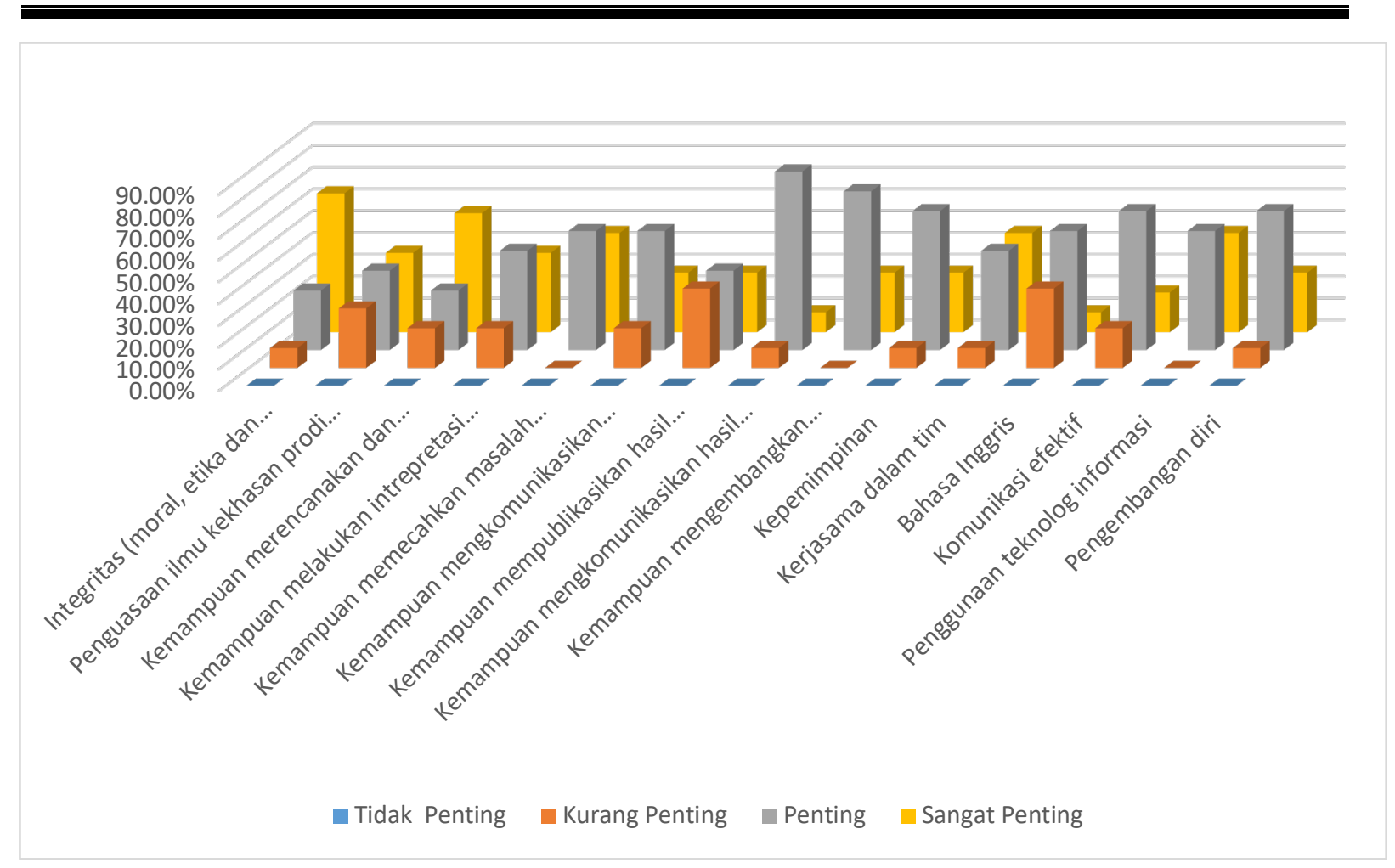

Grafik Error! No text of specified style in document.-4 Pendapat Responden Alumni Tentang Kompetensi Soft dan Hard Skills Dibutuhkan Dalam Pekerjaan 
Dalam Tabel Error! No text of specified style in document.-4 dan Grafik Error! No text of specified style in document.-4 tergambar bahwa kebutuhan kompetensi soft dan hard skills responden alumni dalam rangka dapat membantu penyelesaian masalah di organisasi dan lingkungan didominasi oleh pernyataan pada tingkat penting dan sangat penting. Pernyataan mereka yang tertinggi tentang kebutuhan kompetensi ini adalah pada item kemampuan mengkomunikasikan hasil penelitian dalam forum ilmiah di tingkat nasional atau internasional, yaitu sebanyak 81,82 persen menyatakan penting. Yang juga menyatakan sebanyak 72,73 persen pentingnya kemampuan mengembangkan pengetahuan dan mengintegrasikannya dengan ilmu pengetahuan mutakhir. Dalam penelitian ini juga mendapati bahwa mereka menyatakan sebanyak 63,64 persen sangat penting memiliki integritas (moral, etika dan profesionalisme). Mereka juga menyatakan bahwa sebanyak masingmasing 63,64 persen pentingnya kompetensi mereka dalam hal: kepemimpinan, komunikasi efektif, dan pengembangan diri. Kebutuhan kompetensi kerjasama dalam tim dinyatakan oleh responden alumni, yaitu sebanyak masing-masing 45,45 persen menyatakan penting dan sangat penting.

\section{Kinerja atau Daya Saing}

Salah satu tujuan akhir dari suatu pendidikan adalah kemampuan atau kinerja lulusan dalam memperoleh pekerjaan dalam waktu singkat setelah mereka dinyatakan lulus dari jenjang pendidikannya. Dalam penelitian ini indikator yang dipergunakan dalam melihat kinerja alumni adalah kemampuan mereka bersaing memperoleh pekerjaan dalam kurun waktu kurang dari 6 (enam) bulan terhitung dari saat mereka dinyatakan lulus dari Prodi MIE UNRAM.
Dari hasil wawancara diperoleh bahwa seluruh atau 100,00 persen responden alumni menyatakan mendapat pekerjaan dalam kurun waktu kurang dari 6 (enam) bulan yang sesuai dengan bidang kajian selama kuliah di Prodi MIE UNRAM. Disamping itu pula, mereka juga menyatakan bahwa sebanyak 45,45 persen sangat mampu untuk bersaing dengan alumni perguruan tinggi lain baik dalam memperoleh dan dalam pekerjaan. Juga dinyatakan oleh sebanyak 54,55 persen alumni bahwa mereka mampu bersaing dengan alumni perguruan tinggi lain. Menurut mereka, apabila Prodi MIE UNRAM dapat mempertimbangkan, memperhatikan, memenuhi kebutuhan soft dan hard skills yang mereka perlukan, kemampuan bersaing mereka semakin tinggi dibandingkan dengan alumni perguruan tinggi lain.

\section{Kesimpulan}

Dari hasil analisis dan pembahasan dapat disimpulkan bahwa:

- Pengalaman magang dalam suatu instansi atau organisasi sangat penting bagi alumni untuk melihat pengalaman praktik teori ekonomi dalam dunia nyata. Para alumni juga perlu penekanan besar terhadap peragaan atau demontrasi dalam proses pembelajaran dalam rangka visualisasi teori ekonomi secara kasat mata untuk mempermudah pemahaman teori yang bersifat abstrak. Pembimbingan akademik mendapatkan penilaian besar dalam proses pembelajaran karena alumni telah lama meniggalkan bangku kuliah strata satu. Untuk mereka memerlukan bimbingan akademik secara baik formal maupun informal. 
- Ada beberapa kemampuan soft dan hard skills yang alumni perlukan yang terungkap dalam penelitian ini, yaitu, kemampuan mengkomunikasikan hasil penelitian ke forum ilmiah baik tingkat nasional maupun tingkat internasional, juga memerlukan kemampuan untuk melakukan pengembangan diri, dan integritas yang tinggi untuk mengahadapi kebutuhan profesionalisme kekinian.

- Hingga saat ini, alumni masih memiliki kemampuan bersaing dalam tingkatan mampu dan sangat mampu berhadapan dengan alumni perguruan tinggi lain. Kemampun bersaing ini dalam rangka memperoleh pekerjaan dan melakukan pekerjaan di instansi atau organisasi dimana mereke berkerja.

Saran

Berdasarkan simpulan di atas dapat disarankan bahwa:

Untuk dapat memenuhi keperluan magang di suatu instansi dapat dilakukan dengan memberikan tugas yang memerlukan penyelesaian dengan ikut terlibat dalam suatu proses tertentu (contoh: proses penyusunan Rencana Pembangunan Jangka Menengah PEMKAB Tertentu) dalam suatu instansi atau organisasi. Keperluan visualisasi teori dapat dilakukan dengan simulasi baik secara konsep (computer based simulation) maupun fisik. Untuk bimbingan intansif, pengajar atau dosen pembimbing dapat melakukan bimbangan secara berkelompok dalam suatu forum formal atau/ dan informal baik di kampus maupun di luar kampus.

> Mahasiswa dilibatkan dalam seminar atau workshop pada tingkat nasional dan internasional. Mengadakan kuliah umum yang disampaikan oleh tokoh yang menjadi tauladan di masyarakat nasional dan internasional. Tokoh ini harus memiliki integritas yang tinggi yang bebas dari kasus korupsi.

> Melakukan dan melaksanakan saran-saran di atas agar mahasiswa lebih memiliki latar pengetahuan dan pengalaman yang komprehensif dalam bidang ilmu ekonomi untuk mampu bersaing memperoleh pekerjaan dan penyelesaian pekerjaan dalam taraf nasional dan internasional.

\section{Daftar Kepustakaan}

Gibson, J.L; J.M Ivancevich, \& J.H. Donelly, Jr. 1988. Organizations: Behavior, Structure, Processes. Plano: Business Publications Inc.

MattesonM.T. et.al. 1989. Management and Organizational Behavior Classics. Homewood: BPI/IRWIN.

Milton, C.R. 1981. Human Behavior in Organization. Englewood Cliffs: Prentice Hall, Inc.

Minner, J.B. 1985. The Principle of Management. Columbus: Charles E.Merill Publishing Company. 